\title{
Analisa Perbandingan Kesehatan Bank Menggunakan Metode Camels
}

(Studi Kasus pada Bank Konvensional dan Bank Syariah yang Terdaftar di Bursa Efek Indonesia Periode 2015-2019)

\author{
Santy Pujaraniam \\ Universitas Sarjanawiyata Tamansiswa \\ spujaraniam@gmail.com
}

\section{Sri Hermuningsih}

Universitas Sarjanawiyata Tamansiswa

hermun_feust@yahoo.co.id

\section{Agus Dwi Cahya \\ Universitas Sarjanawiyata Tamansiswa \\ agusdc@ustjogja.ac.id}

\begin{abstract}
Abstrak Penelitian ini bertujuan untuk mengetahui apakah terdapat perbedaan antara tingkat kesehatan bank konvensional dan bank syariah pada periode 2015-2019. Penelitian ini menggunakan metode CAMELS yang terdiri dari Capital, Asset, Management, Earnings, Liquidity dan Sensitivity to Market Risk agar mengetahui bagaimana kondisi kesehatan suatu bank tersebut. Pada aspek permodalan menggunakan rasio Capital Adequacy Ratio, Non Performing Loan mewakili aspek aset, Net Profit Margin mewakili aspek manajemen, Return On Assets, Return On Equity, Biaya Operasional dan Pendapatan Operasional mewakili aspek rentabilitas, Loan To Deposit Ratio mewakili aspek likuiditas dan Interest Expense Ratio mewakili aspek sensitivitas terhadap risiko pasar. Jenis penelitian yang digunakan adalah penelitian deskriptif kuantitatif dengan menggunakan perangkat lunak SPSS 16. Sumber data pada penelitian ini adalah data sekunder. Teknik pengambilan sampelnya menggunakan purposive sampling. Metode pengumpulan datanya adalah data sekunder. Data yang digunakan dalam penelitian ini merupakan data - data sekunder yang diperoleh melalui situs Bursa Efek Indonesia dan situs resmi setiap sampel bank yaitu berupa laporan keuangan perusahaan selama 5 tahun. Penelitian ini menggunakan uji normalitas dan uji beda atau analisis perbandingan Independent Sample T-test untuk analisis statistik dan uji hipotesis. Hasil analisis ini menemukan tidak terdapat perbedaan antara tingkat kesehatan bank konvensional dan syariah pada rasio Capital Adequacy Ratio, Loan To Deposit Ratio dan Interest Expense Ratio, namun terdapat perbedaan pada rasio Non Performing Loan, Net Profit Margin, Return On Assets, Return On Equity, dan Biaya Operasional dan Pendapatan Operasional. Maka dapat disimpulkan bahwa bank konvensional memiliki kondisi kesehatan yang lebih baik dibandingkan bank syariah selama periode 2015-2019.
\end{abstract}




\section{Kata Kunci Perbandingan, Tingkat Kesehatan Bank, Bank Konvensional, Bank Syariah, Camels}

\section{PENDAHULUAN}

Perbankan merupakan lembaga keuangan yang sangat penting peranannya dalam kegiatan ekonomi, karena melalui kegiatan perkreditan dan berbagai jasa yang diberikan oleh bank maka dapat melayani berbagai kebutuhan pada berbagai sektor ekonomi dan perdagangan, sehingga dapat dikatakan bahwa bank merupakan inti dari sistem keuangan setiap negara. Undang - Undang No.21 Tahun 2008 menyatakan bahwa ada dua jenis perbankan di Indonesia yaitu bank konvensional dan bank syariah. Bank konvensional kegiatan usahanya berdasarkan pembayaran bunga sedangkan bank syariah kegiatan usahanya berdasarkan prinsip syariah tanpa bunga.

Perkembangan industri perbankan telah mengalami perubahan besar dalam beberapa tahun terakhir khususnya pada dunia perbankan di Indonesia kini makin ramai dengan adanya bank syariah, yang kegiatan operasionalnya berbeda dibandingkan dengan bank konvensional yang sudah lama ada. Kebanyakan masyarakat di Indonesia lebih familiar terhadap bank konvensional dibanding bank syariah, hal ini disebabkan kurangnya sosialisasi oleh pemerintah sehingga kesadaran dan minat masyarakat terhadap perbankan. syariah masih minim. Pada tahun 2019 bank syariah dianggap masih lambat bersaing dengan bank konvensional terutama pada kondisi selama lima tahun kebelakang. Perlambatan ini membuat bank syariah selalu menjadi pembahasan terutama pada masalah permodalan, likuiditas dan efisiensi.

Setiap bank pasti memiliki kinerja nya masing - masing. Untuk menilai kinerja perusahaan perbankan pada umumnya digunakan enam aspek penilaian yaitu : Capital (Permodalan), Asset Quality (Kualitas Aset), Management (Manajemen), Earnings (Rentabilitas), Liquidity (Likuiditas), Sensitivity To Market Risk (Sensitivitas terhadap Risiko Pasar). Aspek permodalan diukur menggunakan rasio Capital Adequacy Ratio atau CAR (Rasio kecukupan modal yang berguna untuk menampung risiko kerugian yang kemungkinan dihadapi bank. Aspek aset tercermin dalam Non Performing Loan atau rasio NPL yang dapat melihat resiko kredit dengan kemungkinan kegagalan klien membayar kewajibannya atau resiko dimana nasabah tidak dapat melunasi hutang. Aspek manajemen yaitu Net Profit Margin atau NPM adalah rasio yang dapat mengukur kemampuan bank dalam menghasilkan laba bersih dari kegiatan operasi pokoknya. Aspek rentabilitas tercermin dalam Return On Assets atau ROA, Return On Equity atau ROE dan Biaya Operasional dan Pendapatan Operasional atau BOPO yang menunjukkan tingkat kemampuan bank untuk memperoleh laba dari aktivitas usahanya. Jika tingkat laba suatu bank semakin tinggi, maka akan berdampak pada meningkatnya modal sendiri dengan asumsi besarnya laba yang diperoleh ditanamkan kembali ke dalam modal bank dalam bentuk laba ditahan. Aspek Loan To Deposit atau rasio LDR merupakan posisi likuiditas untuk menjaga kesehatan bank dalam jangka pendek. Aspek sensitivitas terhadap resiko pasar menggunakan rasio Interest Expense Ratio (IER) yang merupakan ukuran atas biaya dana yang dikumpulkan oleh bank yang dapat menunjukkan efisiensi bank didalam mengumpulkan sumber-sumber dananya. Semakin besar rasio akan semakin buruk, jika semakin kecil akan semakin baik. Berdasarkan penilaian tersebut bertujuan untuk menentukan apakah bank tersebut dalam kondisi yang sehat, cukup sehat, kurang sehat, dan tidak sehat, sehingga Bank Indonesia sebagai pengawas serta pembina 
bank-bank dapat memberikan arahan bagaimana bank tersebut harus dijalankan dengan baik atau bahkan dihentikan operasinya.

Beberapa penelitian terkait dengan tingkat kesehatan bank konvensional dan bank syariah telah dilakukan, diantaranya (Rezky, 2017) tentang analisis tingkat kesehatan bank umum syariah dan bank umum konvensional dengan metode camel periode 20112015 yang hasilnya menyatakan bahwa terdapat perbedaan yang signifikan secara statistik pada variabel CAR, NPL, BDR, NPM, ROA, BOPO dan LAR antara perbankan syariah dan konvensional. Nilai CAR pada bank umum syariah lebih baik dibandingkan bank umum konvensional. Dan nilai NPL, BDR dan LAR yang dimiliki bank umum syariah lebih tinggi dibandingan dengan bank umum konvensional. Perbedaan pada penelitian ini adalah pada tahun penelitian dan variabel yang digunakan yaitu berdasarkan metode CAMELS.

(Handayati, 2015) menganalisis perbandingan kinerja keuangan dengan membandingkan tingkat kesehatan antara bank syari'ah dan bank konvensional di Indonesia periode 2012-2014. Hasil penelitian menunjukkan terdapat perbedaan signifikan antar bank syariah dan bank konvensional. CAR, BDR dan ROA bank syariah tingkat siginifikannya lebih rendah dibandingkan dengan bank konvensional. Sedangkan ROE, BOPO, dan LDR bank syariah tingkat signifikannya lebih tinggi dibandingkan bank konvensional. Perbedaan pada penelitian ini adalah pada tahun penelitian dan varibel yang digunakan.

(Wilson Lupa, Tommy Parengkuan, 2016) berjudul analisis perbandingan tingkat kesehatan perbankan syariah dengan perbankan konvensional dengan metode camel. Alat analisis yang digunakan adalah rasio CAR, NPF, ROA, ROE, dan FDR. Hasil penelitiannya menunjukkan bahwa secara umum, dalam kaitan dengan profitabilitas dan likuiditas perbankan syariah lebih baik dibanding perbankan konvensional. Namun, ada beberapa hal perbankan syariah lebih rendah dari perbankan konvensional terutama dalam CAR, NPF dan ROA. Perbedaan pada penelitian ini adalah pada tahun penelitian dan variabel yang digunakan.

Berdasarkan hal tersebut di atas, dapat diketahui bahwa kesehatan keuangan bank merupakan salah satu faktor penting yang harus diperhatikan oleh perbankan baik konvensional maupun syariah. Terlebih lagi bahwa kini bank syariah sudah mulai umum di telinga masyarakat dan daya tariknya pada sistem bagi hasil yang masih kompetitif dibanding bunga pada bank konvensional. Maka peneliti tertarik untuk meneliti perbedaan tingkat kesehatan bank konvensional dan bank syariah dengan metode CAMELS, dimana obyek penelitian ini terdapat 6 bank konvensional dan 6 bank syariah.

\section{LANDASAN TEORI}

Menurut (Taswan, 2010) bank adalah sebuah lembaga atau perusahaan yang aktivitasnya menghimpun dana berupa giro, deposito tabungan dan simpanan yang lain dari pihak yang kelebihan dana (surplus spending unit) kemudian menempatkannya kembali kepada masyarakat yang membutuhkan dana (deficit spending unit) melalui penjualan jasa keuangan yang pada gilirannya dapat meningkatkan kesejahteraan rakyat banyak.

Untuk menganalisis dan mengevaluasi kinerja keuangan bank dapat menggunakan beberapa metode, salah satu metodenya adalah dengan metode CAMELS. Dalam Peraturan Bank Indonesia No. 6/10/PBI/2004 tanggal 12 April 2004 tentang Sistem Penilaian Tingkat Kesehatan Bank yang merupakan penyempurnaan dari sistem 
penilaian sebelumnya, sehingga penilaian tingkat kesehatan bank meliputi faktor - faktor CAMEL+S. Adapun faktor - faktor tersebut terdiri dari :

a. Faktor Permodalan

Capital Adequacy Ratio (CAR) adalah rasio yang memperlihatkan seberapa jauh seluruh aktiva bank yang mengandung aktiva risiko (kredit, penyertaan, surat berharga, tagihan pada bank lain) ikut dibiayai dari dana modal sendiri bank disamping memperoleh danadana dari sumber diluar bank (Wardiantika \& Kusumaningtias, 2004). Rumus rasio CAR sebagai berikut :

$\mathrm{CAR}=\frac{\text { MOdal Bank }}{\text { ATMR }}$

b. Faktor Kualitas Aset

Non Performing Loan (NPL) / Non Performing Financing (NPF), apabila NPL/NPF menunjukan nilai yang rendah diharapkan pendapatan akan meningkat sehingga laba yang dihasilkan juga akan meningkat, namun sebaliknya apabila nilai NPL/NPF tinggi maka pendapatan akan menurun sehingga laba yang didapat akan turun (Yulianto \& Riyadi, 2014). Rumus rasio NPL sebagai berikut :

NPL $=\frac{\text { Kredit Bermasalah }}{\text { Total Kredit }}$

\section{c. Faktor Manajemen}

Net Profit Margin adalah rasio yang menggambarkan tingkat keuntungan (laba) yang diperoleh bank dibandingkan dengan pendapatan yang diterima dan kegiatan opersional (Dendawijaya, 2009). Rumus rasio NPM sebagai berikut :

$\mathrm{NPM}=\frac{\text { Laba Bersih }}{\text { Pendapatan Operasional }}$

\section{d. Faktor Rentabilitas}

Berikut adalah definisi alat ukur dari aspek rentabilitas :

1) Return On Assets (ROA) digunakan untuk mengukur kemampuan manajemen bank dalam memperoleh keuntungan (laba) secara keseluruhan. Semakin besar ROA suatu bank, semakin beasar pula tingkat keuntungan yang dicapai bank tersebut dan semakin baik pada posisi bank tersebut dan segi penggunaan aset (Dendawijaya, 2009). Adapun rumusnya sebagai berikut:

ROA $=\frac{\text { Laba Sebelum Pajak }}{\text { Total Aktiva }}$

2) Return On Equity (ROE) adalah rasio untuk menunjukkan daya untuk menghasilkan laba atas investasi berdasarkan nilai buku para pemegang saham. Semakin tinggi rasio ini, semakin baik, artinya posisi pemilik perusahaan semakin kuat. Rasio yang paling penting adalah pengembalian atas ekuitas (return on equity), yang merupakan laba bersih bagi pemegang saham di bagi dengan total ekuitas pemegang saham (Brigham \& Houston, 2011). Adapun rumusnya sebagai berikut:

ROE $=\frac{\text { Laba Setelah Pajak }}{\text { Modal Bank }}$

3) BOPO adalah perbandingan antara biaya operasional dengan pendapatan operasional dalam mengukur tingkat efisiensi dan kemampuan bank dalam melakukan kegiatan operasional. Semakin rendah tingkat BOPO berarti semakin baik kinerja manajemen bank tersebut (Prasnanugraha, 2007). Adapun rumusnya sebagai berikut:

$\mathrm{BOPO}=\frac{\text { Beban Operasional }}{\text { Pendapatan Operasional }}$

e. Faktor Likuiditas 
Loan to Deposito Ratio (LDR) adalah rasio antara besarnya seluruh volume kredit atau pembiayaan yang disalurkan oleh bank dan jumlah penerimaan dana dari berbagai sumber. Semakin tinggi rasio tersebut memberikan indikasi semakin rendahnya kemampuan likuiditas bank yang bersangkutan (Dendawijaya, 2009). Adapun rumusnya sebagai berikut :

LDR $=\frac{\text { Total Loans }}{\text { Dana Pihak Ketiga }}$

f. Faktor Sensitivitas terhadap risiko pasar

Interest Expense Ratio (IER) adalah rasio yang mengukur atas biaya dana yang dikumpulkan oleh bank yang dapat menunjukkan efisiensi bank di dalam mengumpulkan sumber-sumber dananya. Interest Expense Ratio (IER) semakin besar rasio akan semakin buruk, jika semakin kecil akan semakin baik. Aspek sensitivitas terhadap resiko pasar dapat diukur dengan:

$\mathrm{IER}=\frac{\text { Interest Expense }}{\text { Total Deposit }}$

\section{METODOLOGI PENELITIAN}

Penelitian ini menggunakan penelitian kuantitatif. Sumber data yang digunakan data sekunder. Data diperoleh dari laporan keuangan yang didapatkan dari www.idx.co.id dan situs resmi perbankan yang menjadi sampel pada penelitian ini. Populasi yang digunakan dalam penelitian ini menggunakan perbankan yang terdaftar di Bursa Efek Indonesia (BEI). Sampel penelitian ini yaitu 12 bank terdiri dari 6 bank konvensional dan 6 bank syariah periode 2015-2019. Teknik pengambilan sampel dalam penelitian ini adalah purposive sampling. Penelitian ini menggunakan uji normalitas dan uji beda.

\section{HASIL PENELITIAN}

\section{Tabel 1.1}

\section{Hasil Uji Statistik Deskriptif}

\section{Descriptive Statistics}

\begin{tabular}{|l|r|r|r|r|r|}
\hline & N & Minimum & Maximum & Mean & Std. Deviation \\
\hline CAR & 60 & 11.5 & 29.7 & 19.593 & 3.5358 \\
NPM & 60 & .3 & 115.0 & 30.376 & 33.3305 \\
ROA & 60 & .0 & 10.8 & 2.034 & 1.7104 \\
ROE & 60 & -94.0 & 29.9 & 9.787 & 15.3218 \\
BOPO & 60 & 58.2 & 217.4 & 85.098 & 21.3614 \\
NPL & 60 & .7 & 12.5 & 3.243 & 1.9669 \\
LDR & 60 & 21.3 & 163.1 & 84.858 & 21.9596 \\
IER & 60 & .92 & 78.63 & 18.6167 & 23.40613 \\
Valid N (listwise) & 60 & & & & \\
\hline
\end{tabular}

Sumber : Data sekunder, 2021, diolah.

Dari tabel 1.1 menunjukkan jumlah sampel 60. Variabel CAR memiliki nilai minimum 11,5 dimana nilai tersebut ada pada bank Panin Dubai Syariah pada tahun 2017. Nilai maksimum sebesar 29,7 dimana nilai tersebut ada pada bank BRI Syariah pada 
tahun 2018. Sementara itu memiliki rata - rata 19,593 dan standar deviasi 3,5358. Pada variabel NPL memiliki nilai minimum 0,7 dimana nilai tersebut ada pada bank BCA tahun 2015 dan BTPN Syariah tahun 2015. Nilai maksimumnya sebesar 12,5 dimana nilai tersebut ada pada bank Panin Dubai Syariah tahun 2017. Sementara itu rata - rata yang dimiliki sebesar 3,243 dan standar deviasi 1.9669. Pada variabel NPM memiliki nilai minimum 0,3 dimana nilai tersebut ada pada bank Bukopin Syariah tahun 2017 dan 2019. Nilai maksimumnya sebesar 115,0 dimana nilai tersebut ada pada bank Mandiri tahun 2019. Sementara itu rata - rata yang dimiliki sebesar 30,37 dan standar deviasi 33,3305. Pada variabel ROA memiliki nilai minimum 0,0 dimana nilai tersebut ada pada bank Bukopin Syariah tahun 2017-2019. Nilai maksimumnya sebesar 10,8 dimana nilai tersebut ada pada bank Panin Dubai Syariah pada tahun 2017. Sementara itu rata - rata yang dimiliki sebesar 2,03 dan standar deviasi 1,7104. Pada variabel ROE memiliki nilai minimum -94,0 dimana nilai tersebut ada pada bank Panin Dubai Syariah tahun 2017. Nilai maksimumnya sebesar 29,9 dimana nilai tersebut ada pada bank BRI pada tahun 2015. Sementara itu rata - rata yang dimiliki sebesar 9,787 dan standar deviasi 15,3218 . Pada variabel BOPO memiliki nilai minimum 58,2 dimana nilai tersebut ada pada bank BCA tahun 2018. Nilai maksimumnya sebesar 217,4 dimana nilai tersebut ada pada bank Panin Dubai Syariah tahun 2017. Sementara itu rata - rata yang dimiliki sebesar 85,098 dan standar deviasi 21,3614. Pada variabel LDR memiliki nilai minimum 21,3 dimana nilai tersebut ada pada bank MANDIRI tahun 2016. Nilai maksimumnya sebesar 163,1 dimana nilai tersebut ada pada bank BTPN Syariah pada tahun 2019. Sementara itu rata - rata yang dimiliki sebesar 84,858 dan standar deviasi 21,9596 dan pada variabel IER memiliki nilai minimum 0,92 dimana nilai tersebut ada pada bank Panin Dubai Syariah tahun 2016. Nilai maksimumnya sebesar 78,63 dimana nilai tersebut ada pada bank Bukopin Syariah pada tahun 2016. Sementara itu rata - rata yang dimiliki sebesar 18,61 dan standar deviasi 23,40613.

Tabel 1.2

Hasil Uji Normalitas

One-Sample Kolmogorov-Smirnov Test

\begin{tabular}{|ll|r|}
\hline & & Unstandardized Residual \\
\hline$N$ & 60 \\
Normal Parameters ${ }^{\mathrm{a}}$ & Mean & .0000000 \\
& Std. Deviation & 1.20312409 \\
Most Extreme Differences & Absolute & .088 \\
& Positive & .088 \\
& Negative & -.058 \\
& & .678 \\
Kolmogorov-Smirnov Z & & .747 \\
Asymp. Sig. (2-tailed) & \\
a. Test distribution is Normal. & \\
b. $\quad$ Calculated from data. &
\end{tabular}

Sumber : Data sekunder, 2021, diolah. 
Dengan uji normalitas ditunjukkan pada tabel 1.2 diketahui bahwa KolmogorovSmirnov $Z$ sebesar 0,747 yang berarti nilai tersebut lebih besar dari 0,05 dan data pada penelitian ini tdapat dinyatakan terdistribusi normal.

Tabel 1.3 Hasil Uji Beda (t-test)

Group Statistics

\begin{tabular}{|c|c|c|c|c|c|}
\hline & Nama Bank & $\mathrm{N}$ & Mean & Std. Deviation & Std. Error Mean \\
\hline CAR & $\begin{array}{l}\text { *BANK KONVENSIONAL* } \\
\text { *BANK SYARAH* }\end{array}$ & $\begin{array}{l}30 \\
30\end{array}$ & $\begin{array}{l}20.212 \\
18.974\end{array}$ & $\begin{array}{l}2.0575 \\
4.5175\end{array}$ & $\begin{array}{l}.3757 \\
.8248\end{array}$ \\
\hline NPM & $\begin{array}{l}\text { *BANK KONVENSIONAL* } \\
\text { *BANK SYARAH }\end{array}$ & $\begin{array}{l}30 \\
30\end{array}$ & $\begin{array}{l}40,416 \\
20,335\end{array}$ & $\begin{array}{l}37.3501 \\
25.6235\end{array}$ & $\begin{array}{l}6.8192 \\
4.6782\end{array}$ \\
\hline ROA & $\begin{array}{l}\text { *BANK KONVENSIONAL* } \\
\text { "BANK SYARAH" }\end{array}$ & $\begin{array}{l}30 \\
30\end{array}$ & $\begin{array}{l}2.628 \\
1.439\end{array}$ & $\begin{array}{l}1.1411 \\
1.9797\end{array}$ & $\begin{array}{l}.2083 \\
.3614\end{array}$ \\
\hline ROE & $\begin{array}{l}\text { *BANK KONVENSIONAL* } \\
\text { *BANK SYARAH" }\end{array}$ & $\begin{array}{l}30 \\
30\end{array}$ & $\begin{array}{l}15.766 \\
13.808\end{array}$ & $\begin{array}{r}6.2876 \\
19.0817\end{array}$ & $\begin{array}{l}1.1480 \\
3.4838\end{array}$ \\
\hline BOPO & $\begin{array}{l}\text { *BANK KONVENSIONAL* } \\
\text { *BANK SYARAH* }\end{array}$ & $\begin{array}{l}30 \\
30\end{array}$ & $\begin{array}{r}74.367 \\
95.829\end{array}$ & $\begin{array}{l}10.7057 \\
23.9895\end{array}$ & $\begin{array}{l}1.9546 \\
4.3799\end{array}$ \\
\hline NPL & $\begin{array}{l}\text { *BANK KONVENSIONAL* } \\
\text { "BANK SYARAH" }\end{array}$ & $\begin{array}{l}30 \\
30\end{array}$ & $\begin{array}{l}2.601 \\
3.884\end{array}$ & $\begin{array}{r}.9181 \\
2.4852\end{array}$ & $\begin{array}{l}.1676 \\
.4537\end{array}$ \\
\hline LDR & $\begin{array}{l}\text { "BANK KONVENSIONAL" } \\
\text { *BANK SYARAH* }\end{array}$ & $\begin{array}{l}30 \\
30\end{array}$ & $\begin{array}{l}81.138 \\
88.578\end{array}$ & $\begin{array}{l}26.4679 \\
15.8711\end{array}$ & $\begin{array}{l}4.8324 \\
2.8977\end{array}$ \\
\hline IER & $\begin{array}{l}\text { *BANK KONVENSIONAL" } \\
\text { "BANK SYARAH* }\end{array}$ & $\begin{array}{l}30 \\
30\end{array}$ & $\begin{array}{l}3.703 \\
3.460\end{array}$ & $\begin{array}{l}1.3209 \\
2.3612\end{array}$ & $\begin{array}{l}.2412 \\
.4311\end{array}$ \\
\hline
\end{tabular}

Sumber :Data sekunder, 2021, diolah.

Tabel 1.4 Hasil Rangkuman Uji Independent Sample T-test

\begin{tabular}{|c|c|c|c|c|}
\hline Variabel & $\boldsymbol{\alpha}$ & $\begin{array}{c}\text { Sig.(2- } \\
\text { tailed) }\end{array}$ & Keterangan & Hasil Hipotesis \\
\hline $\begin{array}{c}\text { Capital Adequacy } \\
\text { Ratio (CAR) }\end{array}$ & 0,05 & 0,179 & $\begin{array}{c}\mathrm{H} 0 \text { diterima (tidak terdapat } \\
\text { perbedaan) }\end{array}$ & H1 ditolak \\
\hline $\begin{array}{c}\text { Non Performing } \\
\text { Loan (NPL) }\end{array}$ & 0,05 & 0,012 & $\begin{array}{c}\text { H0 ditolak (terdapat } \\
\text { perbedaan) }\end{array}$ & $\mathrm{H}$ diterima \\
\hline $\begin{array}{c}\text { Net Profit Margin } \\
\text { (NPM) }\end{array}$ & 0,05 & 0,019 & $\begin{array}{c}\text { H0 ditolak (terdapat } \\
\text { perbedaan) }\end{array}$ & H3 diterima \\
\hline $\begin{array}{c}\text { Return On Assets } \\
\text { (ROA) }\end{array}$ & 0,05 & 0,006 & $\begin{array}{c}\text { H0 ditolak (terdapat } \\
\text { perbedaan) }\end{array}$ & H4 diterima \\
\hline $\begin{array}{c}\text { Return On Equity } \\
\text { (ROE) }\end{array}$ & 0,05 & 0,002 & $\begin{array}{c}\text { H0 ditolak (terdapat } \\
\text { perbedaan) }\end{array}$ & diterima \\
\hline $\begin{array}{c}\text { Biaya Operasional } \\
\text { dan Pendapatan } \\
\text { Operasional } \\
\text { (BOPO) }\end{array}$ & 0,05 & 0,000 & $\begin{array}{c}\text { H0 ditolak (terdapat } \\
\text { perbedaan) }\end{array}$ & H5 ditolak \\
\hline $\begin{array}{c}\text { Loan To Deposit } \\
\text { Ratio (LDR) }\end{array}$ & 0,05 & 0,192 & $\begin{array}{c}\mathrm{H} 0 \text { diterima (tidak terdapat } \\
\text { perbedaan) }\end{array}$ & \\
\hline
\end{tabular}




\begin{tabular}{|c|c|c|c|c|}
\hline $\begin{array}{c}\text { Interest Expense } \\
\text { Ratio (IER) }\end{array}$ & 0,05 & 0,625 & $\begin{array}{c}\mathrm{H} 0 \text { diterima (tidak terdapat } \\
\text { perbedaan) }\end{array}$ & H6 diterima \\
\hline
\end{tabular}

Sumber : Data sekunder, 2021, diolah

a. $\quad$ Perbedaan Tingkat Kesehatan Bank Berdasarkan Faktor Capital

Pada penelitian uji beda variabel Capital Adequacy Ratio (CAR) memiliki nilai Sig. (2tailed) sebesar 0,179>0,05 dengan nilai t sebesar 15,256. Sehingga H0 diterima. Tidak terdapat perbedaan antara tingkat kesehatan bank konvensional dan bank syariah berdasarkan faktor capital melalui Capital Adequacy Ratio (CAR).Dengan hasil penelitian ini maka hipotesis pertama (H1) terdapat perbedaan tingkat kesehatan bank konvensional dan bank syariah berdasarkan faktor capital ditolak. Hasil penelitian ini sejalan dengan penelitian (Wilson Lupa, Tommy Parengkuan, 2016) (Rindawati, 2007) kedua kelompok bank tersebut memiliki kemampuan dalam menyediakan dana untuk menampung risiko kerugian sehingga modal bank dan aktiva tertimbang menurut risiko (ATMR) nya solvable (Wilson Lupa, Tommy Parengkuan, 2016). Namun penelitian ini tidak mengikuti hasil penelitian dari (Rezky, 2017) (Handayati, 2015).

\section{b. Perbedaan Tingkat Kesehatan Bank Berdasarkan Asset}

Selanjutnya pada hasil uji beda dapat dilihat variabel NPL memiliki nilai Sig. (2-tailed) sebesar 0,012 < 0,05 (two-tail) dengan nilai t sebesar 11,089. Sehingga H0 ditolak. Terdapat perbedaan antara tingkat kesehatan bank konvensional dan bank syariah berdasarkan faktor capital melalui Non Performing Loan (NPL). Dengan hasil penelitian ini maka hipotesis kedua (H2) terdapat perbedaan tingkat kesehatan bank konvensional dan bank syariah berdasarkan faktor assets diterima. Hasil penelitian yang mengikuti hasil penelitian (Wilson Lupa, Tommy Parengkuan, 2016) (Rezky, 2017)(Putri \& Dharma, 2016) dan (Kaligis, 2013). Namun penelitian tidak mengikuti hasil penelitian (Ramadhanti, 2015).

\section{c. $\quad$ Perbedaan Tingkat Kesehatan Bank Berdasarkan Management}

Hasil uji beda pada variabel NPM memiliki nilai Sig. (2-tailed) sebesar 0,019<0,05 dengan nilai $\mathrm{t}$ sebesar 2,428. Jadi dapat disimpulkan bahwa Ho ditolak. Terdapat perbedaan antara tingkat kesehatan bank konvensional dengan bank syariah. Dengan hasil penelitian ini maka hipotesis ketiga (H3) terdapat perbedaan tingkat kesehatan bank konvensional dan bank syariah berdasarkan faktor management diterima. Penelitian ini terdukung oleh penelitian (Rezky, 2017) Namun penelitian ini tidak mengikuti hasil penelitian (Yulianto \& Sulistyowati, 2012).

\section{d. Perbedaan Tingkat Kesehatan Bank Berdasarkan Faktor Earnings}

Selanjutnya variabel ROA pada hasil uji beda memiliki nilai Sig. (2-tailed) sebesar 0,006 $<0,05$ dengan nilai t sebesar 2,849. Jadi dapat disimpulkan bahwa H0 ditolak. Terdapat perbedaan antara tingkat kesehatan bank konvensional dengan bank syariah. Dengan hasil penelitian ini maka hipotesis keempat (H4) terdapat perbedaan tingkat kesehatan bank konvensional dan bank syariah berdasarkan faktor Earnings diterima. Hasil penelitian ini mengikuti penelitian (Rezky, 2017) Hasil penelitian ini tidak mengikuti penelitian (Wilson Lupa, Tommy Parengkuan, 2016) (Handayati, 2015).

Selanjutnya pada variabel ROE memiliki nilai Sig. (2-tailed) sebesar 0,002 $<0,05$ dengan nilai t sebesar 3,260. Jadi dapat disimpulkan bahwa H0 ditolak. Terdapat perbedaan antara tingkat kesehatan bank konvensional dengan bank syariah. Dengan hasil penelitian ini maka hipotesis keempat (H4) terdapat perbedaan tingkat kesehatan bank 
konvensional dan bank syariah berdasarkan faktor Earnings diterima. Hasil penelitian ini mengikuti dari (Muchlish \& Umardani, 2016). Namun hasil dari penelitian ini tidak mengikuti penelitian (Wilson Lupa, Tommy Parengkuan, 2016).

Selanjutnya pada variabel BOPO memiliki nilai Sig. (2-tailed) sebesar 0,000 $<0,05$ dengan nilai $\mathrm{t}$ sebesar 4,475. Jadi dapat disimpulkan bahwa H0 ditolak. Terdapat perbedaan antara tingkat kesehatan bank konvensional dengan bank syariah. Dengan hasil penelitian ini maka hipotesis keempat (H4) terdapat perbedaan tingkat kesehatan bank konvensional dan bank syariah berdasarkan faktor Earnings diterima. Hasil penelitian ini terdukung oleh penelitian (Rezky, 2017) Hasil penelitian ini tidak terdukung dari (Yulianto \& Sulistyowati, 2012).

\section{e. $\quad$ Perbedaan Tingkat Kesehatan Bank Berdasarkan Faktor Liquidity}

Pada variabel LDR memiliki nilai Sig. (2-tailed) sebesar 0,192>0,05 dengan nilai $\mathrm{t}$ sebesar 1,320. Jadi dapat disimpulkan bahwa H0 diterima. Tidak ada perbedaan antara tingkat kesehatan bank konvensional dengan bank syariah. Dengan hasil penelitian ini maka hipotesis kelima (H5) terdapat perbedaan tingkat kesehatan bank konvensional dan bank syariah berdasarkan faktor Earnings ditolak. Hasil penelitian ini terdukung oleh peneltian (Rezky, 2017) walaupun istilah kredit (loan) hanya digunakan pada bank konvensional sedangkan pada bank syariah lebih mengarah kepada pembiayaan (financing). Hal tersebut dikarenakan besarnya kredit atau pembiayaan yang disalurkan oleh kedua kelompok bank dan jumlah penerimaan dana dari berbagai sumber telah memenuhi ketentuan yang ditetapkan oleh BI yaitu tidak lebih dari angka 100\%. Hasil penelitian ini tidak terdukung dari (Wilson Lupa, Tommy Parengkuan, 2016).

f. Perbedaan Tingkat Kesehatan Bank Berdasarkan Faktor Sensitivity to Market Risk Variabel IER memiliki nilai Sig. (2-tailed) sebesar 0,000 > 0,05 dengan nilai t sebesar 6386. Jadi dapat disimpulkan bahwa Ho diterima. Tidak terdapat perbedaan antara tingkat kesehatan bank konvensional dengan bank syariah. Dengan hasil penelitian ini maka hipotesis keenam (H6) tidak terdapat perbedaan tingkat kesehatan bank konvensional dan bank syariah berdasarkan faktor Earnings diterima. Hasil penelitian ini mengikuti penelitian (Valensya, 2018) dan (Fivtina Marbelanty, 2015). Penelitian ini tidak mengikuti penelitian dari(Yulianto \& Sulistyowati, 2012).

\section{KESIMPULAN}

Berdasarkan hasil analisis data dan pembahasan yang mengacu pada masalah dan tujuan, diperoleh hasil pada periode 2015-2019 terdapat perbedaan antara tingkat kesehatan bank konvensional dan bank syariah pada faktor assets yaitu NPL, management yaitu NPM, dan earnings yaitu ROA, ROE, dan BOPO. Sedangkan tidak terdapat perbedaan antara tingkat kesehatan bank konvensional dan bank syariah pada faktor capital yaitu CAR, liquidity yaitu LDR dan faktor sensitivitas to market risk yaitu IER. Pada rasio CAR bank konvensional memiliki rasio sebesar 20,21 dan bank syariah sebesar 18,974. Kedua kelompok bank dikategorikan sangat sehat. Rasio NPL pada bank konvensional dan syariah masing - masing memiliki rasio 2,6 dan 3,8 maka kedua kelompok bank tersebut dikategorikan sehat. Rasio NPM bank konvensional dan syariah memiliki rasio masing - masing 40,41 dan 20,33 maka kedua kelompok bank tersebut dikategorikan tidak sehat. Pada rasio ROA bank konvensional memiliki rasio sebesar 2,6 maka dapat dikategorikan sangat sehat sedangkan bank syariah rasio ROA nya sebesar 1,4 maka dapat dikategorikan sehat. Rasio ROE bank konvensional sebesar 15,7 maka 
dapat dikategorikan sangat sehat sedangkan bank syariah sebesar 13,8 maka dikategorikan sehat. Rasio BOPO bank konvensional dan syariah masing - masing sebesar 74,3 dan 95,8 maka dapat dikategorikan masing - masing sangat sehat dan cukup sehat. Pada rasio LDR bank konvensional memiliki 81,1 maka dapat dikategorikan sehat dan syariah sebesar 88,57 maka dikategorikan cukup sehat. Rasio IER pada bank konvensional dan syariah masing - masing sebesar 3,7 dan 3,4 maka kedua kelompok bank tersebut dapat dikategorikan sehat karena berada pada rasio dibawah 5\%. Dari hasil tersebut dapat disimpulkan bahwa kondisi kesehatan bank pada bank konvensional dan bank syariah lebih baik dibandingkan bank syariah selama periode 2015-2019.

\section{DAFTAR PUSTAKA}

Brigham, E. F., \& Houston, J. F. (2011). Dasar-dasar manajemen Keuangan (Buku 2 Edisi 1Brigham, E. F., \& Houston, J. F. (2011). Dasar-dasar manajemen Keuangan (Buku 2 - Edisi 11). In Salemba Empat.1). In Salemba Empat.

Dendawijaya, L. (2009). Manajemen Perbankan. Jakarta: Ghalia Indonesia.

Fivtina Marbelanty, A. 1. (2015). Analisis Perbandingan Kinerja Keuangan antara Perbankan Konvensional Dengan Perbankan Syariah di Indonesia. Journal of Accounting, 4(No. 1), 1-10.

Handayati, P. (2015). ANALYSIS COMPARATIVE OF FINANCIAL PERFORMANCE OF SYARI ' AH AND CONVENTIONAL BANKING IN INDONESIA. 3(11), 4152.

Kaligis, Y. (2013). Analisis Tingkat Kesehatan Bank Dengan Menggunakan Metode Camel Pada Industri Perbankan Bumn Yang Terdaftar Di Bursa Efek Indonesia. Jurnal Riset Ekonomi, Manajemen, Bisnis Dan Akuntansi, 1(3), 263-272. https://doi.org/10.35794/emba.v1i3.2015

Muchlish, A., \& Umardani, D. (2016). Bank Konvensional Di Indonesia. Jurnal Manajemen Dan Pemasaran Jasa, 9(1), 129-156.

Prasnanugraha, P. (2007). Analisis Pengaruh Rasio-rasio Keuangan Terhadap Kinerja Bank Umum di Indonesia (Studi Empiris Bank-bank Umum Yang Beroperasi Di Indonesia). Tesis, 1-65.

Putri, E., \& Dharma, A. B. (2016). ANALISIS PERBEDAAN KINERJA KEUANGAN ANTARA BANK KONVENSIONAL DENGAN BANK SYARIAH. Riset Akuntansi Dan Keuangan Indonesia. https://doi.org/10.23917/reaksi.v1i2.2734

Ramadhanti, A. F. (2015). ANALISIS CAMELS DALAM MEMPREDIKSI TINGKAT KESEHATAN BANK YANG TERDAFTAR DI BURSA EFEK INDONESIA PERIODE 2011-2015. Skripsi.

Rezky, F. (2017). Analisis Tingkat Kesehatan Bank Umum Syariah Dan Bank Umum Konvensional Dengan Metode CAMEL Periode 2011-2015. Skripsi, 171. 
Rindawati, E. (2007). ANALISIS PERBANDINGAN KINERJA KEUANGAN PERBANKAN SYARIAH DENGAN PERBANKAN KONVENSIONAL.

Taswan. (2010). Manajemen Perbankan: Konsep, Teknik, dan Aplikasi. In Yogyakarta: UPP STIM YKPN Yogyakarta.

Valensya, C. S. (2018). Analisis Tingkat Kesehatan Bank Dengan Metode Camel Studi Perbandingan Pada BRI Tbk \& BTN Tbk Periode 2010-2014. Skripsi. Retrieved from papers2://publication/uuid/512EBCE8-D635-4348-A67D-22DD52988F4C

Wardiantika, L., \& Kusumaningtias, R. (2004). Pengaruh Dpk, Car, Npf, Dan Swbi Terhadap Pembiayaan Murabahah Pada Bank Umum Syariah Tahun 2008-2012. Jurnal Ilmu Manajemen (JIM).

Wilson Lupa, Tommy Parengkuan, J. S. (2016). Comparative Analysis of Health Level of Conventional Banking and Islamie Banking With the Camel Method. Jurnal Berkala Ilmiah Efisiensi, 16(01), 694-705.

Yulianto, A., \& Riyadi, S. (2014). Pengaruh Pembiayaan Bagi Hasil , Pembiayaan Jual Beli , Pembiayaan Jual Beli, Financing To Deposit Ratio (FDR) dan Non Performing Financing (NPF) Terhadap Profitabilitas Bank Umum Syariah Di Indonesia. Jurnal Akuntansi.

Yulianto, A., \& Sulistyowati, W. A. (2012). Analisis CAMELS Dalam Memprediksi Tingkat Kesehatan Bank Yang Terdaftar Di Bursa Efek Indonesia Periode Tahun 2009 - 2011. Media Ekonomi \& Teknologi Informasi. 